\title{
ANALISIS FRONTIER EFFICIENCY INDUSTRI PERBANKAN INDONESIA DENGAN MENGGUNAKAN METODE DISTRIBUTION FREE APPROACH
}

\author{
Agus Herta Sumarto $^{1}$, Iman Sugema ${ }^{2}$, Nunung Nuryartono ${ }^{2}$ \\ ${ }^{1}$ Mahasiswa Magister Program Studi Ilmu Ekonomi, FEM IPB \\ ${ }^{2}$ Staf Pengajar FEM IPB
}

Artikel diterima September 2013

Artikel disetujui untuk dipublikasikan Desember 2013

\begin{abstract}
As an intermediary institution, bank has a very vital role in the economic development of a country so bank has to operate efficiently. The efficiency analysis can be conducted with the three approaches, namely cost efficiency, profit efficiency, and alternative profit efficiency. The three approaches can measured with two methode, parametric and non parametric. By using parametric methode (Distribution Free Approach), cost efficiency of 107 commercial banks operating for 10 years (20022011), the average cost efficiency of banks in Indonesia is 0.6729. While the average value of the profit efficiency in Indonesian banks is 0.96363 or more efficient than cost efficiency. The score of alternative profit efficiency Indonesian banks is 0.965957. The cost efficiency of commercial banks on average have no strong correlation with all financial ratios of banks. The profit efficiency have a strong relationship with financial ratios $R O A$ and BOPO. Financial performance of the bank's $R O E$ ratio has a moderate correlation with the level of profit efficiency. While the level of alternative profit efficiency have a strong relationship with financial performance ratios ROE, ROA, and ROA. NIM ratio has a low relationship with alternative profit efficiency.
\end{abstract}

Keyword: Distributin Free Approach, Cost Efficiency, Profit Efficiency, and Alternative Profit Efficiency.

\section{PENDAHULUAN Latar Belakang}

Pemberlakuan

Masyarakat Ekonomi ASEAN (MEA) yang akan dimulai pada tahun 2015 sedikit besar akan mempengaruhi sistem dan kondisi perekonomian di negara-negara ASEAN termasuk Indonesia. Pemberlakukan pasar tunggal yang diharapkan lebih kompetitif dengan prinsip kesetaraan (equality) di antara negara-negara anggota akan meningkatkan persaingan ekonomi antar negara-negara tersebut. Dengan adanya MEA, para pelaku ekonomi kawasan ASEAN akan lebih mudah menanamkan modalnya dan melakukan usaha di negara-negara ASEAN sehingga persaingan usaha diharapkan lebih kompetitif.

Dalam kerangka MEA, setelah pengintegrasian sektor riil pada 2015 2020, pada tahun 2020 akan dimulai pengintegrasian sektor keuangan yang dimulai dari pasar bebas perbankan 
ASEAN. Dengan adanya pengintegrasian sektor keuangan maka persaingan lembaga perbankan di antara negara-negara di ASEAN akan semakin meningkat. Bahkan dalam menyambut pengintegrasian sektor keuangan ini, BI sudah melakukan berbagai kajian mengenai ASEAN Banking Integration Framework (ABIF) yang salah satunya adalah kajian mengenai penyiapan bank berskala ASEAN atau qualified ASEAN banks (QAB).

Dari catatan Biro Riset Infobank setidaknya ada empat pilar yang akan menjadi acuan ABIF yaitu harmonisasi regulasi prudensial, kesiapan infrastruktur stabilitas keuangan, capacity building bagi negara ASEAN yang relatif tertinggal, dan kesepakatan mengenai kriteria QAB. Sedangkan dari sisi efisiensi, dengan rasio biaya operasional terhadap pendapatan operasional (BO/PO) sekitar 74,94 persen dan rasio net interest margin (NIM) 5,41 persen pada posisi Juli 2012, industri perbankan nasional dituntut untuk bisa lebih efisien lagi. Hal ini dikarenakan rata-rata rasio BOPO dan NIM perbankan di lima negara besar ASEAN masing-masing hanya berada pada kisaran 56,75 persen dan 3,53 persen.

Efisiensi saat ini menjadi tantangan yang harus diperhatikan oleh pelaku industri perbankan di Indonesia. Pendalaman pasar keuangan Indonesia sampai saat ini masih tertinggal dari beberapa negara besar di ASEAN. Rasio kredit terhadap produk domestik bruto (PDB) Indonesia di antara negara-negara Asia dan ASEAN masih termasuk rendah yaitu hanya 29,62 persen per tahun 2011 masih jauh di bawah China, Singapura, Malaysia, dan Thailand. Hal ini harus menjadi perhatian serius para pelaku industri perbankan di Indonesia karena dengan kondisi seperti ini maka penetrasi bank-bank dari negara ASEAN lainnya akan semakin besar.

Tabel 1 Rasio Kredit Terhadap PDB Beberapa Negara Tahun 2011

\begin{tabular}{lr}
\hline Negara & \multicolumn{2}{c}{$\begin{array}{c}\text { Rasio Kredit } \\
\text { terhadap PDB }(\%)\end{array}$} \\
\hline China & 140 \\
Singapura & 128.6 \\
Malaysia & 117.7 \\
Thailand & 92.97 \\
Indonesia & 29.62 \\
Cambodia & 27.6 \\
Laos & 20.4 \\
\hline
\end{tabular}

Sumber: World Bank dalam Majalah Infobank (2012)

Pasca pengalihan fungsi pengawasan bank dari BI ke Otoritas Jasa Keuangan (OJK), pada beberapa tahun ke depan tingkat efisiensi lembaga perbankan akan menjadi fokus penilaian OJK dalam hal kebijakan pemberian ijin bagi bank yang akan berekspansi bisnis baik produk maupun layanan. Tingkat efisiensi bank akan menjadi salah satu pertimbangan dan penilaian OJK dalam pemberian ijin tersebut. Indikator penilaian tingkat efisiensi bank yang digunakan oleh OJK saat ini masih seperti penilaian yang dilakukan oleh BI yaitu NIM dan BOPO.

Jika dilihat dari indikator yang dulu digunakan oleh BI dan sekarang oleh OJK maka akan terlihat bahwa BOPO dan NIM perbankan Indonesia selama tujuh tahun terakhir relatif tidak banyak mengalami perubahan. Nilai NIM perbankan Indonesia selama tujuh tahun terakhir tetap berada di atas 5,5 persen. Sedangkan untuk nilai BOPO, selama tujuh tahun terakhir masih ada pada kisaran 84 persen sampai dengan 89 persen.

Sebenarnya selama beberapa tahun terakhir ini bank-bank di Indonesia membukukan keuntungan yang sangat bagus. Bahkan dari 10 perusahaan Indonesia yang masuk ke dalam 2000 perusahaan terbesar di dunia menurut 
versi Forbes, lima diantaranya adalah lembaga perbankan. Hal ini menunjukkan bahwa kinerja lembaga perbankan di Indonesia dari sisi pendapatan sudah sangat bagus.

Walaupun dari sisi pendapatan hampir semua bank di Indonesia mengalami peningkatan namun nilai BOPO selama tujuh tahun terakhir relatif stabil di atas 84 persen. Hal ini disebabkan karena seiring dengan peningkatan pendapatan operasional, biaya operasional bank juga mengalami peningkatan sehingga tidak berpengaruh besar pada nilai BOPO. Seiring dengan peningkatan laba, bank-bank di Indonesia juga melakukan ekspansi bisnis dengan menambah berbagai infrastruktur seperti penambahan kantor cabang dan mesin Anjungan Tunai Mandiri (ATM).

Tabel 2 Kinerja Keuangan Perbankan Nasional

\begin{tabular}{lrrrrrr}
\hline KETERANGAN & \multicolumn{1}{l}{ 2007 } & \multicolumn{1}{l}{2008} & \multicolumn{1}{l}{2009} & \multicolumn{1}{l}{2010} & \multicolumn{1}{l}{2011} & 2012 \\
\hline DALAM RP TRILIUN & & & & & & \\
\hline - ASET TOTAL & 1986.5 & 2310.56 & 2534.11 & 3008.85 & 3652.83 & 4262.5 \\
- DANA PIHAK KETIGA & 1510.83 & 1753.29 & 1950.71 & 2338.82 & 2784.91 & 3225.0 \\
* GIRO & 405.56 & 430 & 465.22 & 535.86 & 652.65 & 767.0 \\
* DEPOSITO & 666.71 & 824.7 & 899.78 & 1069.81 & 1233.97 & 1381. \\
* TABUNGAN & 438.57 & 498.59 & 585.71 & 733.16 & 898.3 & 1076.8 \\
- KREDIT & 1002.01 & 1307.69 & 1437.93 & 1765.85 & 2216.54 & 2725.6 \\
- AKTIVA PRODUKTIF (AP) & 1851.99 & 2242.28 & 2464.26 & 2831.87 & 3426.35 & 3930.6 \\
- MODAL DISETOR & 78.93 & 86.28 & 96.3 & 105.52 & 112.72 & 123.2 \\
- LABA TAHUN BERJALAN & 35.02 & 30.61 & 45.22 & 57.31 & 75.08 & 92.8 \\
\hline DALAM PERSEN (\%) & & & & & & \\
\hline - ROA & 2.78 & 2.33 & 2.6 & 2.86 & 3.03 & 3.1 \\
- LDR & 66.32 & 74.58 & 72.88 & 75.21 & 78.77 & 83.5 \\
- NPLs (gross) & 4.07 & 3.2 & 3.31 & 2.56 & 2.17 & 1.8 \\
- BOPO & 84.05 & 88.59 & 86.63 & 86.14 & 85.42 & 74. \\
- CAR & 19.3 & 16.76 & 17.42 & 17.18 & 16.05 & 17.4 \\
- KREDIT / AP & 54.1 & 58.32 & 58.53 & 62.36 & 64.69 & 69.3. \\
- NIM & 5.7 & 5.66 & 5.56 & 5.73 & 5.91 & 5.4 \\
\hline SUIm & & & & & \\
\hline
\end{tabular}

Sumber: Bank Indonesia (2013)

Ekspansi usaha yang dilakukan oleh bank beberapa tahun terakhir ini didasari pada ekspektasi positif kondisi ekonomi politik nasional. Stabilitas iklim politik dua periode pemerintahan ini setidaknya telah mengakibatkan pertumbuhan ekonomi yang stabil. Kestabilian dalam bidang politik berimbas pada kondisi ekonomi yang relatif stabil dan kondusif sehingga menciptakan optimisme para pelaku ekonomi. Hal inilah yang kemudian menjadikan para pelaku ekonomi termasuk industri perbankan memiliki ekspektasi yang positif sehingga berimbas pada ekspansi bisnisnya.

Oleh karena itu, untuk menilai tingkat efisiensi bank alangkah baiknya jika melihat secara komprehensif dengan memasukan berbagai variabel penilaian tidak hanya sebatas pada nilai BOPO dan NIM saja. Peran bank sebagai lembaga intermediasi harus dilihat secara lebih menyeluruh baik dari aspek pendapatan bank itu sendiri maupun dari aspek biaya yang dikeluarkan oleh bank tersebut. Dengan memasukkan beberapa variabel kinerja keuangan bank maka tingkat efisiensi suatu bank akan bisa dilihat lebih objektif baik dilihat dari sisi pendapatan bank maupun dari sisi biaya yang dikeluarkan oleh bank dalam menjalankan peran dan fungsinya tersebut.

Pengukuran tingkat efisiensi bank dengan menggunakan pendekatan metode parametrik dan non parametrik ini bukanlah hal yang baru. Akhtar pada tahun 2010 melakukan penelitian mengenai tingkat efisiensi bank di Pakistan dengan menggunakan data dari tahun 2001 sampai tahun 2006. Metode yang digunakan adalah Data Envelopment Analysis (DEA) dan hasilnya menunjukkan bahwa tingkat efisiensi bank di Pakistan masih rendah.

Repkova dan Miglietti (2014) meneliti tingkat efisiensi biaya dan keuntungan sektor perbankan di Slovakia periode 2003-2012 dengan menggunakan metode Stochastic Frontier Approach (SFA). Dari hasil penelitian mereka diperkirakan nilai efisiensi biaya rata-rata berkisar 29-92 persen. Sedangkan nilai efisiensi keuntungan rata-rata berkisar antara 5693 persen. Hasil penelitian mereka juga menunjukkan bahwa bank-bank kecil 
dan menengah di Slovakia lebih efisien daripada bank-bank besar.

Pada tahun 2014 penelitian mengenai sektor perbankan juga pernah dilakukan di Arab Saudi oleh Sillah dkk. (2014). Penelitian Sillah mencoba menganalisis tingkat efisiensi teknis perbankan di Arab Saudi dengan menggunakan model stochastic frontier. Penelitian Sillah mengambil 12 bank sebagai sampel selama periode tahun 2000-2011. Bank yang diambel sebagai sampel dibedakan menjadi tiga kelompok yaitu bank milik pemerintah, bank milik asing, dan bank syariah. Dari hasil penelitian ditemukan perbedaan yang signifikan antara bank-bank tersebut dalam hal efisiensi teknis. Bank yang paling efisien adalah bank asing sedangkan bank milik pemerintah kinerja efisiensinya berfluktuasi selama periode penelitian dan jenis bank syariah tidak berbeda secara signifikan dari milik pemerintah.

Di belahan benua Eropa, Banerjee (2012) menganalisis tingkat efisiensi bank di negara-negara yang baru masuk menjadi anggota Uni Eropa. Banerjee mengukur peringkat relatif efisiensi masing-masing negara dan pengaruh struktur kepemilikan terhadap kinerja bank. Teknik yang digunakan adalah DEA, SFA, dan DFA dengan mengukur tingkat efisiensi biaya, keuntungan, dan keuntungan alternatif. Hasil penelitiannya memperlihatkan bahwa teknik penghitungan dan konsep yang berbeda akan menghasilkan hasil yang berbeda untuk peringkat efisiensi, tetapi beberapa pola umum adalah sudah sama. Dari penelitiannya ditemukan bahwa Ceko menjadi negara paling efisien dari sisi teknis dan keuntungan namun terendah dalam hal efisiensi biaya. Sedangkan bank-bank di Slovenia dan Estonia menjadi bank paling efisien dari sisi biaya.
Di Indonesia penelitian mengenai
tingkat efisiensi bank dengan menggunakan DEA, SFA, dan DFA sudah banyak dilakukan, salah satunya adalah Hadad dkk. (2003). Hadad et al. (2003) juga pernah melakukan penelitian yang serupa dengan menggunakan metode parametrik (SFA dan DFA). Hasilnya menunjukkan berdasarkan metode parametrik, skor efisiensi DFA lebih beragam dibandingkan dengan skor efisiensi SFA, jika digunakan data bulanan dan data tahunan yang menggabungkan seluruh bank. Namun demikian, bank-bank yang paling efisien yang dihasilkan dengan menggunakan kedua metode adalah sama. Sehingga perhitungan dengan menggunakan DFA dan SFA jika menggunakan observasi seluruh bank menghasilkan nilai-nilai yang konsisten.

Oleh karena itu, penelitian mengenai efisiensi bank akan selalu menjadi hal yang menarik. Setiap tahun bank akan menghadapi kondisi pasar dan ekonomi yang berbeda sehingga penelitian mengenai tingkat efisiensi bank akan menghadapi kondisi kebaruan setiap tahunnya.

\section{Tujuan Penelitian}

1. Menganalisis tingkat efisiensi biaya bank umum;

2. Menganalisis tingkat efisiensi keuntungan bank umum;

3. Menganalisis tingkat efisiensi keuntungan lainnya bank umum; dan

4. Menganalisis hubungan tingkat efisiensi biaya, keuntungan, dan keuntungan alternatif bank umum dengan Capital Adequacy Ratio (CAR), Beban Operasional terhadap Pendapatan Operasional (BOPO), Return on Asset (ROA), Return on Equity (ROE), Net Interest Margin (NIM), dan Loan to Deposit Ratio (LDR). 


\section{TINJAUAN PUSTAKA}

\section{Pengertian Bank dan Bank Umum}

Pengertian bank di Indonesia saat ini masih merujuk pada Undang-undang (UU) Nomor 10 Tahun 1998 tentang Perubahan Undang-undang Nomor 7 Tahun 1992 Tentang Perbankan (Sekretariat Negara, 1998). Dalam UU tersebut disebutkan bahwa yang dimaksud dengan bank adalah suatu badan usaha yang menghimpun dana dari masyarakat dalam bentuk simpanan dan menyalurkan kepada masyarakat dalam bentuk kredit dan atau dalam bentuk-bentuk lainnya dalam rangka meningkatkan taraf hidup orang banyak. Dalam UU tersebut juga dijelaskan bahwa terdapat dua macam bank berdasarkan fungsinya yaitu Bank Umum dan Bank Perkreditan Rakyat (BPR). Bank Umum adalah bank yang melaksanakan kegiatan usaha secara konvensional dan atau berdasarkan Prinsip Syari'ah yang dalam kegiatannya memberikan jasa dalam lalu lintas pembayaran.

\section{Konsep Efisiensi}

Berdasarkan review komprehensif yang dilakukan oleh Berger dan Humphrey (1997) terhadap 130 studi tentang efisiensi lembaga keuangan di 21 negara diketahui setidaknya ada dua pendekatan untuk mengukur efisiensi di lembaga perbankan yaitu pendekatan non parametrik dan pendekatan parametrik. Metode yang biasa digunakan untuk pendekatan non parametrik adalah Data Envelopment Analysis (DEA) dan Free Disposal Hull (FDH). Sedangkan untuk pendekatan parametrik metode yang biasa digunakan adalah Stochastic Frontier Analysis (SFA), Distribution Free Approach (DFA) dan Thick Frontier Approach (TFA). Jika dilihat dari konsep efisiensi dalam industri perbankan maka pendekatan pengukuran nilai efisiensi bank dapat dibedakan menjadi tiga yaitu cost efficiency, profit efficiency, dan alternative profit efficiency. Cost efficiency mengukur tingkat kedekatan jumlah biaya yang dikeluarkan oleh suatu bank dengan jumlah biaya yang dikeluarkan oleh bank terbaik (best practice bank) untuk menghasilkan jumlah output yang sama dalam kondisi yang sama. Standard profit efficiency mengukur seberapa dekat sebuah bank kepada tingkat maksimum profit yang mungkin dihasilkan pada tingkat hargaharga input dan output tertentu. Sedangkan alternative profit efficiency mengukur seberapa dekat suatu bank kepada perolehan profit maksimum dengan tingkat output tertentu, bukan tingkat harga dari output. Jika dilihat dari hubungan input - output fungsi bank, nilai efisiensi bank dapat diperoleh dengan menggunakan dua pendekatan yaitu pendekatan produksi (the production approach), dan pendekatan intermediasi the intermediation approach) (Sealey dan Lindley, 1977).

\section{Konsep DFA}

Metode DFA adalah salah satu metode penghitungan nilai efisiensi dengan pendekatan parametrik yang dikembangkan oleh Allen N. Berger pada tahun 1993 dengan tujuan membuat alternatif penghitungan nilai efisiensi selain SFA. Berger membangun pendekatan DFA untuk menggantikan beberapa asumsi statistik yang ketat dalam pendekatan SFA dengan asumsi sederhana dalam dekomposisi residual. Pendekatan ini mengasumsikan bahwa perbedaan biaya (dalam konteks efisiensi biaya) yang berkaitan dengan inefisiensi biaya adalah stabil sepenjang waktu dimana komponen acak (random error) bervariasi dan cenderung mendekati rata-ratanya yaitu nol.

Fungsi biaya dengan pendekatan DFA dapat dituliskan dalam bentuk di bawah ini: 


$$
C=C\left(w, y, z, v, u_{C}, \varepsilon_{C}\right)
$$

Dimana $C$ adalah variabel biaya, $w$ adalah variabel harga input, $\mathrm{y}$ adalah kuantitas output, $\mathrm{z}$ adalah kuantitas fixed netputs, $\mathrm{v}$ adalah kondisi lingkungan, $\mathrm{u}_{\mathrm{c}}$ adalah faktor inefisiensi, sedangkan $\varepsilon_{\mathrm{C}}$ menggambarkan random error.

Fungsi keuntungan dengan pendekatan DFA dapat dituliskan dalam bentuk di bawah ini:

$$
\pi=\varepsilon\left(w, p, z, v, u_{C}, \in_{C}\right)
$$

Dalam fungsi keuntungan hampir semua variabel sama dengan variabel pada fungsi biaya kecuali $\pi$ yang menggambarkan variabel keuntungan, dan $\mathrm{p}$ yang menggambarkan variabel harga output.

Fungsi keuntungan lainnya dengan pendekatan DFA dapat dituliskan dalam bentuk di bawah ini:

$$
\pi=\varepsilon\left(w, y, z, v, u_{C}, \in_{C}\right)
$$

Dalam fungsi keuntungan lainnya hampir semua variabel sama dengan variabel keuntungan kecuali variabel $p$ yang menggambarkan variabel harga output diganti dengan variabel y yang menggambarkan kuantitas output.

\section{METODOLOGI PENELITIAN}

\section{Jenis dan Sumber Data}

Penelitian ini menggunakan data sekunder, yakni laporan keuangan publikasi bank yang terdapat dalam direktori Bank Indonesia (BI). Data yang digunakan adalah data publikasi bank selama 10 tahun yaitu tahun 2002 2011. Periode tahun 2002 - 2011 diambil sebagai tahun pengamatan karena selama periode tersebut bank dinilai sudah melalui tahap recovery pascakrisis ekonomi tahun 1997/1998. Data yang digunakan adalah data panel yang berasal dari seluruh bank umum di Indonesia periode tahun 2002 - 2011 yang terdiri dari (1). Bank Persero, (2). Bank Swasta Devisa, (3). Bank Swasta Non Devisa, (4). Bank Campuran, (5).
Bank Asing, dan (6). Bank Pembangunan Daerah (BPD). Jumlah total bank yang diteliti sebanyak 107 karena bank Syariah dan bank-bank yang tidak memiliki laporan keuangan lengkap selama periode pengamatan tidak dimasukkan dalam objek penelitian.

\section{Definisi Operasional}

Variabel-variabel yang digunakan dalam penelitian ini disesuaikan dengan laporan keuangan bank yang berlaku di Indonesia dari tahun 2002 sampai dengan tahun 2011. Variabel-variabel yang digunakan juga berbeda untuk setiap pendekatan. Variabel yang digunakan pendekatan Profit Effciciency dapat dilihat dalam Tabel 3. Sedangkan variabel yang digunakan untuk pendekatan Cost Efficiency dan Alternative Profit Efficiency relatif sama hanya beda dalam variabel depdendennya. Variabel yang digunakan untuk pendekatan Cost Efficiency dan Alternative Profit Efficiency dalam dilihat dalam Tabel 4.

Tabel 3 Variabel Penelitian dengan Pendekatan Profit Efficiency

\begin{tabular}{|c|l|l|l|l|l|}
\hline No & \multicolumn{1}{|c|}{$\begin{array}{l}\text { Jenis } \\
\text { Variabel }\end{array}$} & \multicolumn{1}{|c|}{ Variabel } & $\begin{array}{c}\text { Nama } \\
\text { Variabel }\end{array}$ & Simbol & Keterangan \\
\hline 1 & \multicolumn{2}{|l|}{ Dependen } & $\begin{array}{l}\text { Pendapatan } \\
\text { Operasional }\end{array}$ & $\pi$ & $\begin{array}{l}\text { Pendapatan } \\
\text { Operasional }\end{array}$ \\
\hline 2 & & Input & $\begin{array}{l}\text { Harga } \\
\text { Beban } \\
\text { Bunga }\end{array}$ & $\mathrm{w}$ & $\begin{array}{l}\text { Beban } \\
\text { Bunga / } \\
\text { Liabilitas }\end{array}$ \\
\hline 3 & Output & $\begin{array}{l}\text { Harga } \\
\text { Output }\end{array}$ & $\mathrm{p}$ & $\begin{array}{l}\text { Pendapatan } \\
\text { Bunga / } \\
\text { Total Aset }\end{array}$ \\
\hline 4 & Fixed Netput & $\begin{array}{l}\text { Net } \\
\text { Komitmen }- \\
\text { Kontijensi }\end{array}$ & $\mathrm{z} 1$ & $\begin{array}{l}\text { Komitmen - } \\
\text { Kontijensi }\end{array}$ \\
\hline 5 & Fixed Netput & Modal Fisik & $\mathrm{z} 2$ & $\begin{array}{l}\text { Akumulasi } \\
\text { Penyusutan } \\
\text { Aset }\end{array}$ \\
\hline 6 & & Fixed Netput & Aset & $\mathrm{z} 3$ & Total Aset \\
\hline 7 & Independen & Enviromental & $\begin{array}{l}\text { Non } \\
\text { Performing } \\
\text { Loan }\end{array}$ & NPL & Gross NPL \\
\hline
\end{tabular}

Untuk mengontrol heteroskedastisitas dalam setiap persamaan maka setiap variabel dalam penelitian ini dibagi oleh variabel total aset. Selain itu, perlakuan ini diharapkan 
dapat memberikan interpretasi yang lebih baik secara ekonomi. Dalam manajemen perbankan, pendapatan yang dibagi dengan aset (ROA) menjadi salah satu indikator utama dalam pencapaian tujuan perusahaan (bank).

Tabel 4 Variabel Penelitian dengan Pendekatan Cost Efficiency dan Alternative Profit Efficiency

\begin{tabular}{|c|c|c|c|c|c|}
\hline No & $\begin{array}{c}\text { Jenis } \\
\text { Variabel }\end{array}$ & Variabel & $\begin{array}{c}\text { Nama } \\
\text { Variabel }\end{array}$ & Simbol & Keterangan \\
\hline 1 & Dependen & & $\begin{array}{l}\text { Pendapatan } \\
\text { Operasional }\end{array}$ & $\pi$ & $\begin{array}{l}\text { Pendapatan } \\
\text { Operasional }\end{array}$ \\
\hline 2 & Dependen & & \begin{tabular}{|l|} 
Biaya \\
Operasional
\end{tabular} & c & \\
\hline 3 & & Input & $\begin{array}{l}\text { Harga Beban } \\
\text { Bunga }\end{array}$ & w & $\begin{array}{l}\text { Beban Bunga } \\
\text { / Liabilitas }\end{array}$ \\
\hline 4 & & Output & \begin{tabular}{|l|} 
Kredit \\
Properti
\end{tabular} & $\mathrm{y} 1$ & \begin{tabular}{|l|} 
Kredit \\
Properti
\end{tabular} \\
\hline 5 & & Output & $\begin{array}{l}\text { Kredit Non } \\
\text { Properti }\end{array}$ & $\mathrm{y} 2$ & $\begin{array}{l}\text { Total Kredit - } \\
\text { Kredit } \\
\text { Properti }\end{array}$ \\
\hline 6 & & Output & $\begin{array}{l}\text { Aktiva } \\
\text { Produktif } \\
\text { Selain Kredit }\end{array}$ & y3 & \begin{tabular}{|l|} 
Total Aktiva \\
Produktif- \\
Kredit \\
Properti- \\
Kredit Non \\
Properti
\end{tabular} \\
\hline 7 & & Fixed Netput & \begin{tabular}{|l|} 
Net \\
Komitmen - \\
Kontijensi
\end{tabular} & $\mathrm{zl}$ & $\begin{array}{l}\text { Komitmen - } \\
\text { Kontijensi }\end{array}$ \\
\hline 8 & & Fixed Netput & Modal Fisik & 22 & \begin{tabular}{|l|} 
Akumulasi \\
Penyusutan \\
Aset
\end{tabular} \\
\hline 9 & & Fixed Netput & Aset & $\mathrm{z3}$ & Total Aset \\
\hline 10 & Independen & Enviromental & \begin{tabular}{|l|} 
Non \\
Performing \\
Loan \\
\end{tabular} & NPL & Gross NPL \\
\hline
\end{tabular}

\section{Model Penelitian}

Berdasarkan hubungan input output fungsi bank, pendekatan yang digunakan dalam penelitian ini adalah pendekatan intermediasi (the intermediation approach). Pendekatan intermediasi memandang bank sebagai intermediator dimana bank berfungsi merubah dan mentransfer aset-aset finansial dari unit-unit surplus menjadi unit-unit defisit. Dalam hal ini inputinput institusional adalah pembayaran bunga pada deposit, dengan output yang diukur dalam bentuk kredit pinjaman (loans) dan investasi finansial (financial investments).

Dalam penelitian ini penggunaan model DFA akan diterapkan dengan pendekatan cost efficiency, standard profit efficiency, dan alternative profit efficiency. Secara matematis model DFA dengan pendekatan cost efficiency dapat mengikuti perhitungan dari Berger dan Mester (1997) sebagaimana rumus berikut:

Cost $E F F^{b}=\frac{\hat{C}^{\text {min }}}{\hat{C}^{b}}=$

$\frac{\exp \left[\hat{f}\left(w^{b}, y^{b}, z^{b}, v^{b}\right)\right] \times \exp \left[\ln \widehat{u}_{c}^{\min }\right]}{\exp \left[\hat{f}\left(w^{b}, y^{b}, z^{b}, v^{b}\right)\right] \times \exp \left[\ln \widehat{u}_{c}^{b}\right]}=$ $\frac{\widehat{u}_{c}^{\min }}{\widehat{u}_{c}^{b}} \ldots(1)$

Nilai cost efficiency akan berkisar dalam interval (0-1) dimana nilai efisiensi satu menunjukkan bahwa bank tersebut merupakan bank yang paling efisien. Model matematis di atas memiliki galat (error term). Setiap galat mempunyai dua komponen, yaitu komponen acak (random effect) dan komponen inefisiensi teknis. Untuk memahami hal tersebut, menurut Berger dan Mester (1997) dikembalikan pada fungsi biaya dan profit dimana inefisiensi dan random error dapat dipisahkan dari fungsi biaya atau profit inti. Inefisiensi $u_{c}$ dan error term $\varepsilon_{\mathrm{c}}$ diasumsikan membentuk fungsi biaya dan profit secara multiplikatif sehingga persamaan biaya dan profit dapat dituliskan dalam bentuk logaritma natural sebagai berikut:

$\ln C=f(w, y, x, v)+\ln u_{c}+\ln \varepsilon_{c}$

(2)

dimana: $\ln C$ adalah total biaya (logaritma natural dari total biaya) dari bank ke-i; $w, y, z, v$ adalah sebuah vektor (transformasi dari) kuantiatas input output dari unit pengambil keputusan kei; $\ln \varepsilon_{\mathrm{c}}$ adalah variabel acak yang diasumsikan independent, identical dan normal distribution (iid), $\mathrm{N}\left(0, \sigma_{\mathrm{V}}{ }^{2}\right)$, dan variabel independen $\ln u$ yang merupakan variabel acak non negatif yang digunakan untuk mengukur tingkat inefisiensi teknis. 
Model DFA dengan pendekatan standard profit efficiency yang mengikuti pendekatan Berger adalah sebagai berikut:

Std $\pi E F F^{b}=\frac{a \pi^{b}}{a \widehat{\pi}^{\max }}=$

$\frac{\left\{\exp \left[\hat{f}\left(w^{b}, p^{b}, z^{b}, v^{b}\right) X \exp \left[\ln \hat{u}_{a \pi}^{b}\right]\right]\right\}-\theta}{\left\{\exp \left[\hat{f}\left(w^{b}, p^{b}, z^{b}, v^{b}\right) X \exp \left[\ln \hat{u}_{a \pi}^{m a x}\right]\right]\right\}-\theta} \ldots$.

dimana semua komponennya sama dengan model cost efficiency hanya ada perubahan pada variabel dependen dan variabel independennya yaitu dari biaya operasional menjadi keuntungan operasional dan variabel kuantitas output menjadi harga output (p). Di samping itu, pada model standard profit efficiency ada penambahan konstanta, $\theta$, yang ditambahkan kepada variabel pendapatan setiap bank sehingga tidak ada bentuk logaritma natural yang nilainya nol (0). Sehingga persamaannya dapat dituliskan sebagai berikut:

$$
\begin{aligned}
& \ln (\pi+\theta)=f(w, p, x, v)+\ln u_{\pi}+ \\
& \ln \varepsilon_{\pi}
\end{aligned}
$$

Sedangkan untuk model DFA dengan pendekatan alternative profit efficiency adalah sebagai berikut:

Alt $\pi E F F^{b}=\frac{a \pi^{b}}{a \widehat{\pi}^{\max }}=$

$\frac{\left\{\exp \left[\hat{f}\left(w^{b}, y^{b}, z^{b}, v^{b}\right) X \exp \left[\ln \widehat{u}_{a \pi}^{b}\right]\right]\right\}-\theta}{\left\{\exp \left[\hat{f}\left(w^{b}, y^{b}, z^{b}, v^{b}\right) X \exp \left[\ln \widehat{u}_{a \pi}^{\max }\right]\right]\right\}-\theta} \ldots$.

dimana semua komponennya sama dengan model cost efficiency hanya ada perubahan pada variabel dependennya yaitu dari biaya operasional menjadi keuntungan operasional. Di samping itu, pada model alternative profit efficiency ada penambahan konstanta, $\theta$, yang ditambahkan kepada variabel pendapatan setiap bank sehingga tidak ada bentuk logaritma natural yang nilainya nol (0). Sehingga persamaannya dapat dituliskan sebagai berikut:

$\ln (\pi+\theta)=f(w, y, x, v)+\ln u_{a \pi}+$
$\ln \varepsilon_{a \pi} \ldots \ldots \ldots \ldots \ldots \ldots \ldots \ldots \ldots \ldots \ldots \ldots \ldots \ldots \ldots \ldots \ldots \ldots \ldots \ldots$
Menurut Berger dan Mester pendekatan alternative profit efficiency akan lebih informatif daripada pendekatan standard profit efficiency jika didasarkan pada kondisi-kondisi berikut:

1. Ada perbedaan yang tidak terukur dalam kualitas pelayanan perbankan.

2. Tidak semua bank dapat mencapai skala ekonomi dan bauran produk karena ada perbedaan output sebagai suatu variabel.

3. Kondisi pasar tidak sepenuhnya kompetitif sehingga sebagian bank memiliki kekuatan pasar di atas bank lain.

4. Harga output yang diukur tidak sepenuhnya akurat sehingga tidak memberikan panduan yang akurat terhadap peluang untuk memperoleh pendapatan dan keuntungan dalam fungsi standard profit.

Efisiensi biaya dengan menggunakan DFA mengukur seberapa dekat biaya dari suatu bank dengan biaya terendah yang dibutuhkan untuk memproduksi output yang sama pada kondisi yang sama. Sedangkan untuk efisiensi profit adalah mengukur seberapa dekat profit yang didapat oleh suatu bank dengan profit tertinggi yang dihasilkan dari produksi yang sama pada kondisi yang sama. Pengukuran efisiensi biaya diturunkan dari fungsi biaya dimana biaya variabel tergantung dari harga dari input variabel, kuantitas dari output, faktor inefisiensi, dan random error. Untuk pengukuran efisiensi profit diturunkan dari fungsi profit dimana profit yang diperoleh tergantung dari harga input variabel, kuantitas dari output, faktor inefisiensi, dan random error. 
Fungsi persamaan alternative profit efficiency menyerupai fungsi persamaan biaya dimana inefisiensi dan random error dapat dipisahkan dari biaya inti. Inefisiensi, $\mathrm{u}_{\mathrm{c}}$, dan error term $\varepsilon_{\mathrm{c}}$ diasumsikan membentuk fungsi alternative profit secara multiplikatif sehingga persamaannya dapat dituliskan dalam bentuk logaritma natural seperti dalam persamaan 3.4. Namun semua variabel dalam penelitian ini sudah dibagi dengan variabel total aset sehingga semua variabel sudah berbentuk rasio. Dalam kondisi seperti ini maka persamaannya tidak ditulis dalam bentuk logaritma natural sehingga penulisan persamaannya adalah:

Persamaan fungsi cost efficiency:

$C=f(w, y, x, v)+u_{c}+\varepsilon_{c}$

Persamaan fungsi standard profit efficiency: $\quad \pi=f(w, p, x, v)+u_{\pi}+$ $\varepsilon_{\pi}$

Persamaan fungsi alternative profit efficiency: $\quad \pi=f(w, y, x, v)+u_{\pi}+$ $\varepsilon_{\pi}$

Dalam perlakuan terhadap komponen galatnya, pendekatan DFA mengasumsikan bahwa perbedaan biaya (dalam konteks biaya) yang berkaitan dengan inefisiensi biaya dan perbedaan profit (dalam konteks profit) yang berkaitan dengan inefisiensi profit, adalah stabil sepanjang waktu, dimana komponen acak (random error) bervariasi dan cenderung mendekati rata-ratanya, yaitu nol. Sehingga perbedaan (residual) tersebut dianggap sebagai inefficiency term. Namun sepanjang waktu tersebut, nilai efisiensi dianggap masih memiliki komponen error. Untuk menghilangkan komponen error tersebut, nilai residual yang tertinggi dan yang terendah dari periode penelitian dihilangkan (truncated). Setelah proses truncated tadi, nilai inefisiensi diperoleh dengan membuat rata-rata dari total residual yang telah mengalami truncated.

Sebagaimana dijelasakan di atas pendekatan variabel-variabel yang digunakan dalam penelitian ini diadopsi dari penelitian Allen N. Berger (1993). Dalam penelitian ini faktor-faktor yang dianggap mempengaruhi tingkat biaya dan keuntungan bank adalah; harga beban bunga, harga output, kredit properti, kredit non properti, aktiva produktif selain kredit, net komitmen kontijensi, modal fisik, aset, dan NPL, sehingga model yang terbentuk adalah:

$$
\begin{gathered}
\text { Cost }=\alpha_{0}+\beta_{1} \cdot w_{i, t}+\beta_{2} \cdot\left(y 1_{i, t} /\right. \\
\left.z 3_{i, t}\right)+\beta_{3} \cdot\left(y 2_{i, t} / z 3_{i, t}\right)+ \\
\beta_{4} \cdot\left(y 3_{i, t} / z 3_{i, t}\right)+ \\
\beta_{5} \cdot\left(z 1_{i, t} / z 3_{i, t}\right)+ \\
\beta_{6} \cdot\left(z 2_{i, t} / z 3_{i, t}\right)+\beta_{7} \cdot N P L+ \\
\varepsilon_{i, t} \cdots \ldots \ldots \ldots \ldots \ldots . .(10) \\
\text { Profit }=\alpha_{0}+\beta_{1} \cdot w_{i, t}+\beta_{2} \cdot p_{i, t}+ \\
\beta_{3} \cdot\left(z 1_{i, t} / z 3_{i, t}\right)+ \\
\beta_{4 \cdot}\left(z 2_{i, t} / z 3_{i, t}\right)+\beta_{5} \cdot N P L+ \\
\varepsilon_{i, t} \cdots \ldots \ldots \ldots \ldots \ldots \ldots \ldots \ldots \ldots . .(11) \\
\text { Alt Profit }=\alpha_{0}+\beta_{1} \cdot w_{i, t}+ \\
\beta_{2} \cdot\left(y 1_{i, t} / z 3_{i, t}\right)+ \\
\beta_{3} \cdot\left(y 2_{i, t} / z 3_{i, t}\right)+ \\
\beta_{4} \cdot\left(y 3_{i, t} / z 3_{i, t}\right)+ \\
\beta_{5} \cdot\left(z 1_{i, t} / z 3_{i, t}\right)+ \\
\beta_{6} \cdot\left(z 2_{i, t} / z 3_{i, t}\right)+ \\
\beta_{7} \cdot N P L+\varepsilon_{i, t} \ldots \ldots \ldots \ldots . .(12)
\end{gathered}
$$

\section{Metode Analisa Data}

Teknik estimasi dalam penelitian ini menggunakan model data panel. Data panel adalah data yang memiliki dimensi ruang (individu) dan waktu (Gujarati, 2004). Dalam data panel, data cross section yang sama diobservasi menurut waktu. Jika setiap unit cross section memiliki jumlah observasi time series yang sama maka disebut sebagai balanced panel (total jumlah observasi $=$ $\mathrm{N} x \mathrm{~T}$ ). Sebaliknya jika jumlah observasi 
berbeda untuk setiap unit cross section maka disebut unbalanced panel.

Baltagi (2005) mengungkapkan bahwa penggunaan data panel memberikan banyak keuntungan, diantaranya sebagai berikut:

1. Mampu mengontrol heterogenitas individu. Dengan metode ini estimasi yang dilakukan dapat secara eksplisit memasukkan unsur heterogenitas individu.

2. Dapat memberikan data yang informatif, mengurangi kolinearitas antar peubah, meningkatkan derajat bebas dan lebih efisien.

3. Lebih baik untuk studi dynamics of adjustment. Karena berkaitan dengan observasi cross section yang berulang, maka data panel lebih baik dalam mempelajari perubahan dinamis.

4. Lebih baik dalam mengidentifikasi dan mengukur efek yang secara sederhana tidak dapat diatasi dalam data cross section saja atau data time series saja.

Selain manfaat yang diperoleh dengan penggunaan panel data, metode ini juga memiliki keterbatasan di antaranya adalah:

1. Masalah dalam desain survei panel, pengumpulan dan manajemen data. Masalah yang umum dihadapi diantaranya: cakupan (coverage), nonresponse, kemampuan daya ingat responden (recall), frekuensi dan waktu wawancara.

2. Distorsi kesalahan pengamatan (measurement errors). Measurement errors umumnya terjadi karena respon yang tidak sesuai.

3. Masalah selektivitas (selectivity) yang mencakup hal-hal berikut:

a. Self-selectivity : permasalahan yang muncul karena data-data yang dikumpulkan untuk suatu penelitian tidak sepenuhnya dapat menangkap fenomena yang ada.

b. Nonresponse : permasalahan yang muncul dalam panel data ketika ada ketidaklengkapan jawaban yang diberikan oleh responden (sampel rumahtangga).

c. Attrition : jumlah responden yang cenderung berkurang pada survei lanjutan yang biasanya terjadi karena responden pindah, meninggal dunia atau biaya menemukan responden yang terlalu tinggi

4. Dimensi waktu (time series) yang pendek. Jenis panel mikro biasanya mencakup data tahunan yang relatif pendek untuk setiap individu.

5. Cross-section dependence. Sebagai contoh, apabila macro panel dengan unit analisis negara atau wilayah dengan deret waktu yang panjang mengabaikan cross-country dependence akan mengakibatkan inferensi yang salah (misleading inference).

Analisis data panel secara garis besar dibedakan menjadi dua macam yaitu statis dan dinamis. Pada analisis data panel dinamis, regressor-nya mengandung variabel lag dependent-nya, sedangkan pada analisis data panel statis tidak. Penelitian ini menggunakan analisis data panel statis sehingga pembahasannya dibatasi untuk analisis statis saja. Secara umum, terdapat dua pendekatan dalam metode data panel, yaitu Fixed Effect Model (FEM) dan Random Effect Model (REM). Keduanya dibedakan berdasarkan ada atau tidaknya korelasi antara komponen error dengan peubah bebas (Baltagi, 2005).

Misalkan diberikan persamaan regresi data panel sebagai berikut:

$Y_{i t}=\alpha_{i}+\beta X_{i t}+$

$\varepsilon_{i t}$ 
dimana:

$$
\begin{array}{cc}
\mathrm{Y}_{\mathrm{it}} & \text { : } \\
& \text { nilai dependent variable } \\
& \text { untuk setiap unit } \\
& \text { individu i pada periode } \mathrm{t} \\
& \text { dimana } \mathrm{i}=1, \ldots, \mathrm{n} \text { dan } \mathrm{t} \\
& =1, \ldots, \mathrm{T} \\
\alpha_{\mathrm{i}} & : \text { unobserved heterogenity } \\
\mathrm{X}_{\mathrm{it}} & \begin{array}{l}
\text { : } \\
\end{array} \\
& \text { nilai independent variable } \\
& \text { yang terdiri dari sejumlah } \\
& \mathrm{K} \text { variabel. }
\end{array}
$$

Struktur dari persamaan regresi data panel dapat dilihat dalam gambar 5 . Pada one way, komponen error dispesifikasikan dalam bentuk:

$\varepsilon_{i t}=\lambda_{i}+u_{i t}$

dimana: $\quad \lambda_{\mathrm{i}}$ : efek individu (time invariant)

$$
\begin{gathered}
\mathrm{u}_{\mathrm{it}}: \begin{array}{c}
\text { disturbance } \\
\text { bersifat }
\end{array} \\
\left(u_{i t} \sim N\left(0, \sigma_{u}^{2}\right)\right)
\end{gathered}
$$

Untuk two way, komponen error dispesifikasikan dalam bentuk:

$$
\varepsilon_{i t}=\lambda_{i}+\mu_{t}+u_{i t}
$$

dimana:

$\mu_{\mathrm{t}} \quad$ : efek waktu (individual invariant)

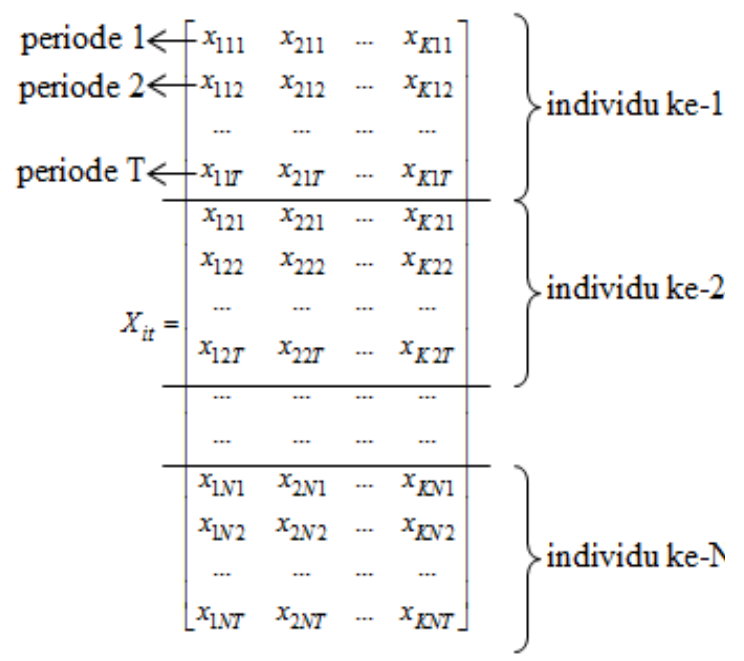

Gambar 1 Struktur data model panel

Pada pendekatan one way komponen error hanya memasukkan komponen error yang merupakan efek dari individu $\left(\lambda_{i}\right)$. Pada two way telah memasukkan efek dari waktu $\left(\mu_{t}\right)$ ke dalam komponen error, $u_{i t}$ diasumsikan tidak berkorelasi dangan $X_{i t}$. Jadi perbedaan antara FEM dan REM terletak pada ada atau tidaknya korelasi antara $\lambda_{i}$ dan $\mu_{t}$ dengan $X_{i t}$.

\section{Fixed Effect Model (FEM)}

Fixed Effect Model digunakan ketika efek individu dan efek waktu mempunyai korelasi dengan $X_{i t}$ atau memiliki pola yang sifatnya tidak acak. Asumsi ini membuat komponen error dari efek individu dan waktu dapat menjadi bagian dari intercept. Untuk one way komponen error:

$Y_{i t}=\alpha_{i}+\lambda_{i}+\beta X_{i t}+u_{i t}$

Sedangkan untuk two way komponen error:

$Y_{i t}=\alpha_{i}+\lambda_{i}+\mu_{t}+\beta X_{i t}+u_{i t}$

Penduga FEM dapat dihitung dengan beberapa teknik, yaitu Pooled Least Square (PLS), Within Group (WG), Least Square Dummy Variable (LSDV), dan Two Way Error Component Fixed Effect Model.

\section{Random Effect Model (REM)}

REM digunakan ketika efek individu dan efek waktu tidak berkorelasi dengan $X_{i t}$ atau memiliki pola yang sifatnya acak. Keadaan ini membuat komponen error dari efek individu dan efek waktu dimasukkan ke dalam error. Untuk one way komponen error:

$Y_{i t}=\alpha_{i}+\beta X_{i t}+u_{i t}+\lambda_{i}$

Untuk two way komponen error:

$Y_{i t}=\alpha_{i}+\beta X_{i t}+u_{i t}+\lambda_{i}+\mu_{t}$ Asumsi yang digunakan dalam REM adalah 


$$
\begin{array}{ll}
E\left(u_{i t} \mid \tau_{i}\right)=0 & \\
E\left(u_{i t}^{2} \mid \tau_{i}\right)=\sigma_{u}^{2} & \text { Dimana untuk: } \\
E\left(\tau_{i} \mid x_{i t}\right)=0 & \text { component: } \\
\text { untuk semua i dan } \mathrm{t} & \tau_{i}=\lambda_{i} \\
E\left(\tau_{i}^{2} \mid x_{i t}\right)=\sigma_{\tau}^{2} & \text { Two way error } \\
\text { untuk semua i dan } \mathrm{t} & \text { component: } \\
E\left(u_{i t} \tau_{j}\right)=0 \text { untuk } & \tau_{i}=\lambda_{i}+\mu_{t} \\
\text { semua i, t, dan } \mathrm{j} & \\
E\left(u_{i t} u_{j s}\right)=0 \text { untuk } & \\
i \neq j \text { dan } t \neq s & \\
E\left(\tau_{i} \tau_{j}\right)=0 \text { untuk } & \\
i \neq j &
\end{array}
$$

Dari semua asumsi di atas, yang paling penting adalah $E\left(\tau_{i} \mid x_{i t}\right)=0$. Pengujian asumsi ini menggunakan HAUSMAN test. Uji hipotesis yang digunakan adalah:

$$
\begin{aligned}
& \mathrm{H} 0: \mathrm{E}\left(\tau_{\mathrm{i}} \mid \mathrm{X}_{\mathrm{it}}\right)=0 \quad \rightarrow \text { Tidak ada } \\
& \text { korelasi antara } \\
& \text { komponen } \\
& \text { error dengan } \\
& \text { peubah bebas } \\
& \mathrm{H} 0: \mathrm{E}\left(\tau_{\mathrm{i}} \mid \mathrm{X}_{\mathrm{it}}\right) \neq 0 \rightarrow \text { Ada korelasi } \\
& \text { antara } \\
& \text { komponen } \\
& \text { error dengan } \\
& \text { peubah bebas } \\
& \begin{array}{c}
H=\left(\hat{\beta}_{R E M}-\hat{\beta}_{F E M}\right)^{\prime}\left(M_{F E M}-M_{R E M}\right)^{-1}\left(\hat{\beta}_{R}\right. \\
\text { dimana } \mathrm{M}: \text { matriks kovarians untuk } \\
\text { parameter } \beta
\end{array} \\
& \mathrm{k} \text { : derajat bebas }
\end{aligned}
$$

Jika $\mathrm{H}>\chi_{\text {tabel }}^{2}$ maka komponen error mempunyai korelasi dengan peubah bebas dan artinya model yang valid digunakan adalah REM. Penduga REM dapat dihitung dengan dua cara yaitu pendekatan Between Estimator (BE) dan Generalized Least Square (GLS).

\section{Pemilihan Model dalam Pengujian Data Panel}

Pemilihan model yang digunakan dalam sebuah penelitian perlu dilakukan berdasarkan pertimbangan statistik. Hal ini ditujukan untuk memperoleh dugaan yang efisien. Diagram pengujian statistik untuk memilih model yang digunakan dapat diperlihatkan pada Gambar 4.

Untuk memutuskan apakah akan menggunakan fixed effect atau random effect menggunakan uji Haussman. Hausman test dilakukan dengan hipotesis sebagai berikut:

Ho: $E\left(\tau_{i} \mid x_{i t}\right)=0$ atau REM adalah model yang tepat

$\mathrm{H}_{1}: E\left(\tau_{i} \mid x_{i t}\right) \neq 0$ atau FEM adalah model yang tepat

Sebagai dasar penolakan $\mathrm{H}_{0}$ maka digunakan statistik Hausman dan membandingkannya dengan Chi square.

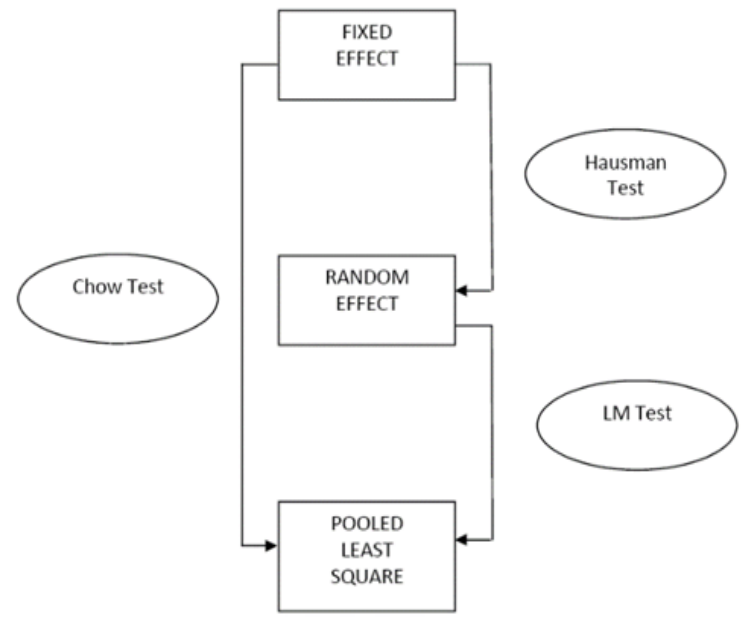

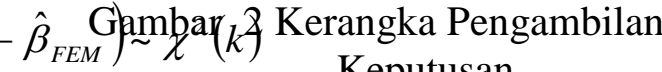

Keputusan

Jika nilai $\chi^{2}$ statistik hasil pengujian lebih besar dari $\chi^{2}$ tabel, maka cukup bukti untuk melakukan penolakan terhadap $\mathrm{H}_{0}$ sehingga pendekatan yang digunakan adalah fixed effect, begitu juga sebaliknya.

\section{Uji Asumsi}

Setelah diputuskan untuk menggunakan suatu model tertentu (FEM atau REM), maka langkah selanjutnya adalah uji asumsi. Dalam melakukan uji asumsi ini ada tiga uji yang harus dilakukan yaitu uji heterskedastisitas, uji 
Uji Multikolinearitas

Indikasi multikolinearitas tercermin dengan melihat hasil $t$ dan $F$ statistik hasil regresi. Jika banyak koefisiensi dari t statistik diduga tidak signifikan smentara dari hasil $\mathrm{F}$ hitungnya signifikan, maka patut diduga adanya masalah multikolinearitas. Multikolinearitas dapat diatasi dengan menghilangkan variabel yang tidak signifikan.

\section{Uji Heteroskedastisitas}

Salah satu asumsi yang harus dipenuhi dalam persamaan regresi adalah bahwa taksiran parameter dalam model regresi bersifat BLUE (Best Linier Unbiased Estimate) maka var $\left(u_{i}\right)$ harus sama dengan $\sigma^{2}$ (konstan), atau semua residual atau error mempunyai varian yang sama. Kondisi itu disebut dengan homoskedastisitas. Sedangkan bila varian tidak konstan atau berubah-ubah disebut dengan heteroskedastisitas. Untuk mendeteksi adanya heteroskedastisitas dapat menggunakan metode General Least Square (Cross section Weights) yaitu dengan membandingkan sum square Resid pada Weighted Statistics dengan sum square Resid unweighted Statistics. Jika sum square Resid pada Weighted Statistics lebih kecil dari sum square Resid unweighted Statistics, maka terjadi heteroskedastisitas.

\section{Uji Autokorelasi}

Autokorelasi adalah korelasi yang terjadi antar observasi dalam satu peubah atau korelasi antar error masa yang lalu dengan error masa sekarang. Uji autokorelasi yang dilakukan tergantung pada jenis data dan sifat model yang digunakan. Autokorelasi dapat mempengaruhi efisiensi dari estimatornya. Untuk mendeteksi adanya korelasi serial dalam penelitian ini digunakan pendekatan tes Wooldridge.
Wooldridge test dilakukan dengan hipotesis sebagai berikut:

H0: Tidak terdapat autokorelasi dalam model

H1: Terdapat autokorelasi dalam model

\section{PERKEMBANGAN BIAYA DAN PENDAPATAN OPERASIONAL BANK}

Selama 10 tahun terakhir industri perbankan di Indonesia mengalami perkembangan yang cukup pesat. Walaupun dari segi jumlah unit lembaga perbankan sedikit mengalami penurunan namun jika dilihat dari segi keuntungan secara rata-rata lembaga perbankan mengalami peningkatan yang signifikan. Selama 10 tahun periode pengamatan hanya dua tahun saja industri perbankan di Indonesia mengalami penurunan keuntungan yaitu periode $2004-2005$ dan periode 2007 - 2008 sebagaimana terlihat pada Gambar 5. Penurunan keuntungan yang terjadi pada periode 2004 - 2005 disinyalir karena mulai meningkatnya biaya pengembangan lembaga bank seiring dengan meningkatnya kesadaran lembaga perbankan untuk meningkatkan fasilitas pelayanan kepada nasabah.

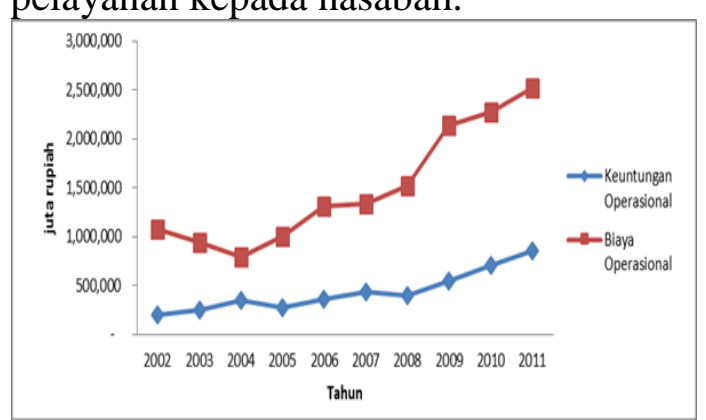

Sumber: Bank Indonesia (Tahun 2002-2011)

Gambar 3 Rata-rata keuntungan dan biaya operasional bank konvensional.

Selama 10 tahun terakhir industri perbankan di Indonesia mengalami perkembangan yang cukup pesat. Walaupun dari segi jumlah unit lembaga 
perbankan sedikit mengalami penurunan namun jika dilihat dari segi keuntungan secara rata-rata lembaga perbankan mengalami peningkatan yang signifikan. Selama 10 tahun periode pengamatan hanya dua tahun saja industri perbankan di Indonesia mengalami penurunan keuntungan yaitu periode 2004 - 2005 dan periode 2007 - 2008 sebagaimana terlihat pada Gambar 5. Penurunan keuntungan yang terjadi pada periode 2004 - 2005 disinyalir karena mulai meningkatnya biaya pengembangan lembaga bank seiring dengan meningkatnya kesadaran lembaga perbankan untuk meningkatkan fasilitas pelayanan kepada nasabah.

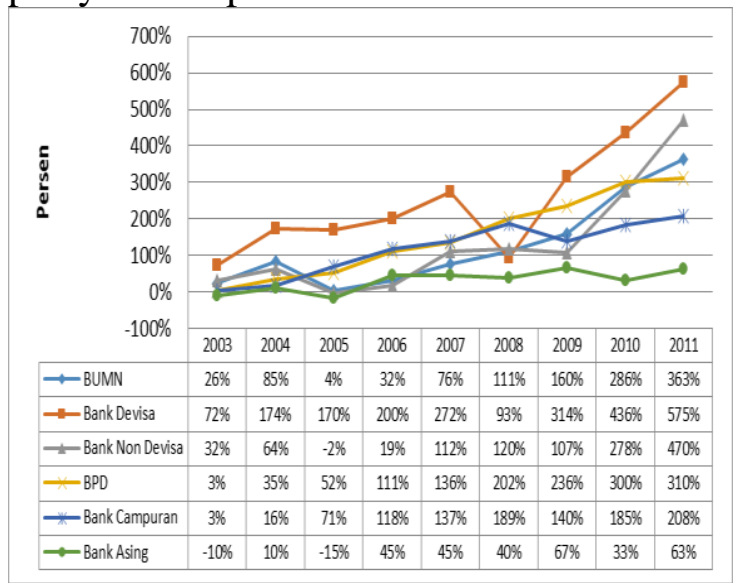

Sumber: Bank Indonesia (Tahun 2002 - 2011)

$\begin{array}{lll}\text { Gambar } \quad 4 & \text { Tren Pertumbuhan } \\ & \text { Keuntungan Berdasarkan } \\ & \text { Kelompok Bank Atas } \\ & \text { Dasar Tahun 2002. }\end{array}$

Sedangkan penurunan keuntungan yang terjadi pada periode 2007 - 2008 disinyalir karena adanya krisis ekonomi global yang berdampak pada penurunan pertumbuhan ekonomi Indonesia. Selain itu, Gambar 5 juga memperlihatkan tren perkembangan rata-rata keuntungan operasional dan biaya operasional bank konvensional dari tahun 2002 sampai dengan tahun 2011. Gambar tersebut memperlihatkan bahwa tingkat biaya operasional industri perbankan hampir setiap tahun mengalami peningkatan.
Namun peningkatan tersebut diikuti dengan peningkatan keuntungan operasional yang diperoleh. Dari gambar tersebut bisa disimpulkan juga bahwa antara biaya opersional dengan pendapatan operasional memiliki hubungan yang positif. Ketika biaya operasional meningkat maka pendapatan operasional juga ikut meningkat.

Jika dilihat tren pertumbuhan keuntungan berdasarkan kelompok bank atas dasar tahun 2002 maka terlihat Bank Umum Devisa memiliki tingkat pertumbuhan paling tinggi dibandingkan bank-bank lainnya seperti terlihat pada Gambar 6. Namun Bank Umum Devisa sempat mengalami penurunan pertumbuhan pada tahun 2008 sampai berada di bawah tingkat pertumbuhan kelompok Bank BUMN, Bank Non Devisa, BPD, dan Bank Campuran. Pada tahun 2011 Bank Non Devisa yang sebelumnya pertumbuhan keuntungannya selalu berada di bawah pertumbuhan keuntungan kelompok bank BUMN dan BPD tumbuh di atas kedua kelompok bank tersebut. Sedangkan kelompok Bank Asing pertumbuhan keuntungannya relatif stabil dan tidak pernah tumbuh di atas angka 70 persen.

\section{EFISIENSI BANK DALAM INDUSTRI PERBANKAN INDONESIA}

\section{Efisiensi Biaya}

Pengukuran nilai efisiensi biaya dari masing-masing bank digunakan tujuh variabel yang terdiri dari biaya operasional, kredit properti, kredit non properti, aktiva produktif selain kredit, net komitmen - kontijensi, modal fisik, dan NPL. Variabel biaya operasional, kredit properti, kredit non properti, aktiva produktif selain kredit, net 
komitmen - kontijensi, dan modal fisik dinormalisasi dengan total aset. Hal ini dilakukan untuk menghilangkan heteroskedastisitas dan efek bank besar dan bank kecil. Berdasarkan hasil analisis regresi data panel model Fixed Effect didapat fungsi biaya sebagai berikut:

$$
\begin{aligned}
\mathrm{C}= & 0,0468-0,1184 \mathrm{Y}_{1}+0,0704 \mathrm{Y}_{2}+ \\
& 0,00005 \mathrm{Y}_{3}+0,01117 \mathrm{Z}_{1}+1,1272 \mathrm{Z}_{2} \\
& +0,00028 \mathrm{NPL}
\end{aligned}
$$

Dari 107 bank yang beroperasi selama 10 tahun terakhir, rata-rata efisiensi biaya bank di Indonesia adalah 0,6729 dengan standar deviasi 0,0787. Nilai maksimum efisiensi biaya bank berdasarkan penghitungan DFA adalah 1,000 dan nilai minimumnya adalah 0,5013 . Bank yang paling efisien dari segi biaya selama 10 tahun terakhir (2002 - 2011) adalah Bank ICBC Indonesia yang merupakan salah satu bank devisa. Sedangkan bank yang berada pada peringkat paling bawah dengan nilai efisiensi 0,5013 adalah JP. Morgan Chase Bank yang termasuk ke dalam kelompok bank asing.

Tabel 5 Statistik Deskriptif Efisiensi Biaya Bank di Indonesia

\begin{tabular}{lcccrr}
\hline & Obs & Mean & Std. Deviation & Minimum & Maximum \\
\hline Efisiensi & 107 & 0.6729 & 0.078701 & 0.5013 & 1 \\
\hline
\end{tabular}

Sumber: Hasil olahan, 2013

Jika nilai efisiensi biaya bank dikelompokkan ke dalam tiga kategori yaitu tingkat efisiensi tinggi, sedang, dan rendah dengan menggunakan metode mean \pm Standard Deviation maka hasilnya dapat dilihat dalam Tabel 3. Tabel 6 Distribusi Nilai Efisiensi Biaya

\begin{tabular}{lrrl}
\hline Nilai Efisiensi & Frekuensi & Persentase & Keterangan \\
\hline $\mathrm{NE}<0,5942$ & 12 & $11,2 \%$ & Efisiensi Rendah \\
$0,5942 \leq \mathrm{NE}<0,7516$ & 87 & $81,3 \%$ & Efisiensi Sedang \\
$\mathrm{NE} \geq 0,7516$ & 8 & $7,5 \%$ & Efisiensi Tinggi \\
\hline
\end{tabular}

Sumber: Hasil olahan, 2013
Jika dilihat berdasarkan kelompok bank maka Bank Campuran memiliki tingkat efisiensi biaya yang paling tinggi selama 10 tahun terakhir diikuti oleh Bank Asing, Bank Pembangunan Daerah, Bank Swasta Nasional Devisa, Bank BUMN, dan Bank Swasta Nasional Non Devisa. Rata-rata nilai efisiensi biaya Bank Campuran selama 10 tahun sebesar 0,7735. Sedangkan kelompok Bank Swasta Nasional Non Devisa sebagai kelompok bank yang memiliki rata-rata nilai efisiensi biaya terendah memiliki rata-rata nilai efisiensi sebesar 0,6451 .

Tabel 7 Rata-rata Nilai Efisiensi Biaya Berdasarkan Kelompok Bank

\begin{tabular}{lr}
\hline Kelompok Bank & Rata-rata Efisiensi \\
\hline Bank Campuran & 0.773532992 \\
Bank Asing & 0.679023718 \\
Bank Pembangunan Daerah & 0.66559756 \\
Bank Swasta Nasional Devisa & 0.659604693 \\
Bank BUMN & 0.649590178 \\
Bank Swasta Nasional Non Devisa & 0.645065108 \\
\hline
\end{tabular}

Sumber: Hasil olahan, 2013

\section{Efisiensi Keuntungan}

Nilai efisiensi keuntungan diperoleh dengan menggunakan enam variabel yaitu pendapatan operasional, harga beban bunga, harga output, net komitmen - kontijensi, modal fisik, dan NPL. Variabel pendapatan operasional, net komitmen - kontijensi, dan modal fisik dinormalisasi dengan total aset. Alasan dilakukannya normalisasi beberapa variabel pada fungsi keuntungan ini sama dengan alasan normalisasi pada fungsi biaya yaitu untuk menghilangkan adanya heteroskedastisitas dan menghilangkan efek bank besar dan bank kecil. Berdasarkan hasil analisis regresi data panel model Fixed Effect didapat fungsi keuntungan sebagai berikut:

$\begin{aligned} \pi= & 0,01468-0,26382 \mathrm{~W}+0,2207 \mathrm{P}+ \\ & 0,00055 \mathrm{Z}_{1}+0,21136 \mathrm{Z}_{2}+ \\ & 0,00059 \mathrm{NPL}\end{aligned}$


Rata-rata nilai efisiensi keuntungan dari 107 bank konvensional yang beroperasi selama 10 tahun adalah 0,96363. Nilai minimum efisiensi keuntungan adalah 0,92338 dan nilai maksiumnya adalah 1 . Bank yang paling maksimum dari segi keuntungan adalah JP. Morgan Chase Bank. Sedangkan bank yang memiliki nilai efisiensi keuntungan paling kecil adalah Bank Andara.

Tabel 8 Statistik Deskriptif Efisiensi Keuntungan Bank di Indonesia Obs Mean Std. Deviation Minimum Maximum

\begin{tabular}{llllll}
\hline Efisiensi & 107 & 0.963633 & 0.01141191 & 0.92338 & 1 \\
\hline
\end{tabular}

Sumber: Hasil olahan, 2013

Bank yang masuk ke dalam kategori bank dengan nilai efisiensi tinggi dalam hal keuntungan berjumlah 15 unit. Bank yang masuk kategori bank dengan efisiensi sedang berjumlah 81 unit atau 75,7 persen. Sedangkan bank yang masuk kategori bank dengan efisiensi rendah berjumlah 11 atau 10,3 persen dari total seluruh bank yang beroperasi selama 10 tahun terakhir.

Tabel 9 Distribusi Nilai Efisiensi Keuntungan

\begin{tabular}{lrrc}
\hline Nilai Efisiensi & Frekuensi & Persentase & Keterangan \\
\hline $\mathrm{NE}<0,9522$ & 11 & $10,3 \%$ & Efisiensi Rendah \\
$0,9522 \leq \mathrm{NE}<0,975$ & 81 & $75,7 \%$ & Efisiensi Sedang \\
$\mathrm{NE} \geq 0,975$ & 15 & $14 \%$ & Efisiensi Tinggi \\
\hline
\end{tabular}

Sumber: Hasil olahan, 2013

Jika diambil rata-rata selama 10 tahun terakhir berdasarkan kelompok bank maka rata-rata nilai efisiensi keuntungan kelompok Bank Asing berada di urutan pertama dengan nilai efisiensi 0,9763. Bank campuran berada di urutan kedua setelah kelompok bank asing dengan nilai 0,9697. Bank Pembangunan Daerah berada di urutan ketiga dengan nilai rata-rata efisiensi yang masih berada di atas rata-rata nilai efisiensi nasional yaitu sebesar 0,96717 .
Tabel 10 Rata-rata Nilai Efisiensi Keuntungan Berdasarkan Kelompok Bank

\begin{tabular}{lr}
\hline Kelompok Bank & lai Efisiensi Keuntungan \\
\hline Bank Asing & 0.97631 \\
Bank Campuran & 0.9697 \\
Bank Pembangunan Daerah & 0.96717 \\
Bank BUMN & 0.96014 \\
Bank Swasta Nasional Devisa & 0.95885 \\
Bank Swasta Nasional Non Devisa & 0.95852 \\
\hline
\end{tabular}

Sumber: Hasil olahan, 2013

Kelompok Bank BUMN berada pada posisi lebih baik dibandingkan dengan rata-rata nilai efisiensi Bank Swasta Nasional Devisa dan Bank Swasta Nasional Non Devisa. Kelompok bank BUMN berada di urutan keempat setelah kelompok bank asing, bank campuran, dan BPD. Namun nilai ratarata tersebut masih berada di bawah ratarata nilai efisiensi keuntungan seluruh bank.

\section{Efisiensi Keuntungan Alternatif}

Nilai efisiensi keuntungan alternatif diukur dengan menggunakan tujuh variabel yang terdiri dari pendapatan operasional, kredit properti, kredit non properti, aktiva produktif selain kredit, net komitmen - kontijensi, modal fisik, dan NPL. Variabel pendapatan operasional, kredit properti, kredit non properti, aktiva produktif selain kredit, net komitmen - kontijensi, dan modal fisik dinormalisasi dengan total aset sebagaimana dilakukan pada fungsi biaya. Alasan dilakukan normalisasi terhadap beberapa variabel sama dengan alasan normalisasi pada fungsi biaya. Berdasarkan hasil analisis regresi data panel model Random Effect didapat fungsi keuntungan alternatif sebagai berikut:

$\pi$ alt $=0,019619-0,0298 \mathrm{Y}_{1}+0,0179 \mathrm{Y}_{2}$ $-0,000025 \mathrm{Y}_{3}-0,00137 \mathrm{Z}_{1}-$ $0,210014 Z_{2}-0,00075 \mathrm{NPL}$ 
Dari 107 bank konvensional yang beroperasi selama 10 tahun terakhir ratarata nilai efisiensi keuntungan alternatif adalah 0,965957. Nilai ini sedikit lebih besar dari rata-rata nilai efisiensi keuntungan. Pun dengan nilai standar deviasinya. Standar deviasi untuk nilai efisiensi keuntungan alternatif sebesar 0,011761 sedangkan untuk nilai standar deviasi efisiensi keuntungan adalah 0,011411. Nilai minimum efisiensi keuntungan alternatif adalah 0,936745 dan nilai maksimumnya adalah 1 . Bank yang memiliki nilai satu atau yang paling maksimum dari segi keuntungan alternatif adalah JP. Morgan Chase Bank. Hasil ini sama dengan hasil yang diperoleh dari analisa efisiensi keuntungan dimana JP. Morgan Chase Bank menempati peringkat pertama dengan nilai efisiensi 1. Sedangkan bank yang memiliki nilai efisiensi keuntungan alternatif paling kecil adalah Bank Andara.

Tabel 11 Statistik Deskriptif Efisiensi Keuntungan Alternatif Bank di Indonesia

\begin{tabular}{llllllr}
\hline & Obs & Mean & Std. Deviation & Minimum & Maximum \\
\hline Efisiensi & 107 & 0.965957 & 0.011761285 & 0.936745 & 1 \\
\hline
\end{tabular}

Sumber: Hasil olahan, 2013

Tabel 9 memperlihatkan bahwa sebagian besar bank masuk ke dalam kategori bank dengan nilai efisiensi sedang yaitu berjumlah 73 bank atau sekitar 68,2 persen dari total keseluruhan bank. Bank yang masuk kategori bank dengan nilai efisiensi tinggi terdapat 15 bank. Sedangkan bank yang masuk ke dalam kategori bank yang memiliki nilai efisiensi rendah ada 19 unit bank atau sekitar 17,8 persen dari total keseluruhan bank.

Tabel 12 Distribusi Nilai Efisiensi Keuntungan Alternatif

\begin{tabular}{lrrc}
\hline \multicolumn{1}{c}{ Nilai Efisiensi } & Frekuensi & Persentase & Keterangan \\
\hline $\mathrm{NE}<0,9542$ & 19 & $17,8 \%$ & Efisiensi Rendah \\
$0,9542 \leq \mathrm{NE}<0,9776$ & 73 & $68,2 \%$ & Efisiensi Sedang \\
$\mathrm{NE} \geq 0,9776$ & 15 & $14 \%$ & Efisiensi Tinggi \\
\hline
\end{tabular}

Sumber: Hasil olahan, 2013

Jika diambil rata-rata selama 10

tahun terakhir berdasarkan kelompok bank maka dari enam kelompok bank hanya dua kelompok bank saja yang nilai rata-rata efisiensinya lebih kecil dari rata-rata nilai efisiensi keuntungan lainnya secara nasional. Kedua kelompok bank tersebut adalah bank swasta nasional devisa dan bank swasta nasional non devisa.

Tabel 13 Rata-rata Nilai Efisiensi Keuntungan Alternatif Berdasarkan Kelompok Bank

\begin{tabular}{lr}
\hline Kelompok Bank & Rata-rata Efisiensi \\
\hline Bank Asing & 0.97464 \\
Bank Pembangunan Daerah & 0.97347 \\
Bank BUMN & 0.96928 \\
Bank Campuran & 0.96739 \\
Bank Swasta Nasional Devisa & 0.96066 \\
BankSwasta Nasional Non Devisa & 0.96008 \\
\hline
\end{tabular}

Sumber: Hasil olahan, 2013

Nilai efisiensi keuntungan lainnya untuk kelompok bank swasta nasional devisa adalah 0,96066 dan nilai efisiensi keuntungan lainnya untuk kelompok swasta nasional non devisa adalah 0,96008 .

\section{Hubungan Efisiensi Biaya, Keuntungan, dan Keuntungan Alternatif dengan Kinerja Keuangan Bank \\ Tingkat efisiensi biaya,} keuntungan, dan keuntungan alternatif lembaga perbankan tidak serta merta memiliki hubungan yang erat dengan seluruh variabel kinerja keuangan yang selama ini menjadi barometer tingkat kesehatan suatu bank. Ada beberapa variabel yang memiliki hubungan namun beberapa variabel yang lain sama sekali tidak memiliki hubungan. Secara lebih jelas tingkat hubungan efisiensi biaya, keuntungan, dan keuntungan alternatif dapat dilihat dalam Tabel 11. 
Tabel 14 Hubungan Efisiensi Biaya, Keuntungan, dan Keuntungan Alternatif dengan Variabel Kinerja Keuangan Bank

\begin{tabular}{|c|c|c|c|}
\hline $\begin{array}{c}\text { Variabel Kinerja } \\
\text { Keuangan }\end{array}$ & $\begin{array}{c}\text { Efisiensi } \\
\text { Biaya }\end{array}$ & $\begin{array}{c}\text { Efisiensi } \\
\text { Keuntungan }\end{array}$ & $\begin{array}{c}\text { Efisiensi } \\
\text { Keuntungan } \\
\text { Alternatif }\end{array}$ \\
\hline$\overline{\text { CAR }}$ & $0,2069^{*}$ & 0,033 & 0,0519 \\
\hline ROE & 0,0718 & $0,5452 *$ & $0,6697 *$ \\
\hline ROA & $0,2654^{*}$ & $0,6834^{*}$ & $0,7318^{*}$ \\
\hline LDR & $0,3284 *$ & $-0,0745$ & $-0,1322$ \\
\hline NIM & $-0,1541$ & 0,1297 & 0,3982 \\
\hline BOPO & $-0,3963^{*}$ & $-0,7452^{*}$ & $-0,7399^{*}$ \\
\hline \multicolumn{4}{|c|}{$\begin{array}{l}\text { * Correlation coefficients is significant at the } 5 \% \\
\text { level or better } \\
* * \text { Correlation coefficients is significant at the } \\
1 \% \text { level or better } \\
\text { Sumber: Hasil olahan, } 2013\end{array}$} \\
\hline
\end{tabular}

\section{SIMPULAN DAN SARAN}

Berdasarkan tujuan, hasil analisis dan pembahasan pada bab sebelumnya, maka penelitian ini dapat menghasilkan beberapa kesimpulan dan saran.

\section{Simpulan}

1. Dilihat dari sisi efisiensi biaya 107 bank umum yang beroperasi selama 10 tahun (2002 - 2011), terakhir rata-rata efisiensi biaya bank di Indonesia adalah 0,6729. Bank yang paling efisien dari segi biaya adalah Bank ICBC Indonesia yang merupakan salah satu bank devisa. Sedangkan bank yang berada pada peringkat paling bawah dengan nilai efisiensi 0,5013 adalah JP. Morgan Chase Bank yang termasuk ke dalam kelompok bank asing.

2. Dalam kurun waktu 10 tahun terakhir (2002 - 2011) rata-rata nilai efisiensi keuntungan 107 bank umum yang beroperasi di Indonesia adalah 0,96363. Nilai efisiensi keuntungan ini jauh lebih baik dibandingkan nilai efisiensi biaya. Bank yang paling efisien dari sisi keuntungan adalah JP. Morgan Chase Bank. Sedangkan bank yang memiliki nilai efisiensi keuntungan paling rendah adalah
Bank Andara dengan nilai efisiensi 0,92338 .

3. Dari 107 bank umum yang beroperasi selama 10 tahun terakhir rata-rata nilai efisiensi keuntungan lainnya adalah 0,965957. Nilai ini sedikit lebih besar dari rata-rata nilai efisiensi keuntungan. Bank yang paling efisien dari sisi keuntungan lainnya adalah JP. Morgan Chase Bank. Sedangkan bank yang memiliki nilai efisiensi keuntungan lainnya paling rendah adalah Bank Andara dengan nilai efisiensi sebesar 0,9367 .

4. Efisiensi biaya bank umum secara rata-rata tidak memiliki hubungan dengan dua rasio keuangan bank yaitu ROE dan NIM. Sedangkan untuk rasio kinerja keuangan lainnya yaitu CAR, ROA, LDR, dan BOPO hubungannya relatif rendah. Jika dilihat dari sisi efisiensi keuntungan maka secara rata-rata efisiensi keuntungan memiliki hubungan yang relatif kuat dengan rasio keuangan ROA dan BOPO. Rasio keuangan kinerja bank ROE memiliki tingkat hubungan yang relatif lebih kecil dibanding dengan ROA dan BOPO. Sedangkan hubungan antara efisiensi keuntungan dengan rasio kinerja keuangan CAR, LDR, dan NIM bisa dikatakan tidak memiliki hubungan. Sedangkan tingkat efisiensi keuntungan alternatif memiliki hubungan yang relatif kuat dengan rasio kinerja keuangan ROE, ROA, dan BOPO. Rasio NIM memiliki hubungan yang relatif rendah dengan tingkat efisiensi keuntungan alternatif. Sedangkan rasio CAR dan LDR bisa dikatakan tidak memiliki hubungan dengan tingkat efisiensi keuntungan alternatif. 


\section{Saran}

Berdasarkan hasil penelitian, beberapa saran yang dapat disampaikan adalah sebagai berikut:

1. Persaingan bisnis bank di Indonesia akan semakin meningkat. Hanya bank-bank yang efisiensi yang bisa bertahan dalam persaiangan yang semakin tinggi. Jika dilihat dari sisi efisiensi biaya maka rata-rata bank di Indonesia masih belum efisien. Oleh karena itu, setiap bank di Indonesia harus bisa meningkatkan efisiensi biayanya. Perluasan ekspansi pasar dalam negeri yang mengakibatkan tingkat efisiensi biaya menurun harus dikaji lebih mendalam. Sebaiknya bank-bank kecil dan menengah fokus pada pasar tertentu baik dari segi demografi maupun usaha sehingga tingkat efisiensi biayanya tidak terlalu rendah.

2. Walaupun tingkat efisiensi keuntungan dan keuntungan alternatif bank-bank di Indonesia telah melampaui angka 90 persen, potensi keuntungan pasar Indonesia masih besar. Bank-bank di Indonesia masih banyak melakukan operasi usahanya di pulau Jawa khususnya kota-kota besar seperti Jakarta, Bandung, Semarang, dan Surabaya. Sebelum masuknya bank-bank QAB sebaiknya bank-bank yang sekarang telah beroperasi semakin menguatkan pasar di dalam negeri terutama untuk pasar-pasar yang belum tersentuh lembaga perbankan sehingga efisiensi keuntungannya bisa lebih tinggi lagi.

3. Lembaga perbankan dan BI tidak hanya menjadikan rasio-rasio kinerja keuangan konvensional sebagai barometer utama dalam mengukur tingkat efisiensi suatu bank. Pengukuran melalui frontier analysis dengan pendekatan biaya, keuntungan, dan keuntungan alternatif layak untuk dipertimbangkan.

4. Saran untuk penelitian selanjutnya berhubungan dengan pendekatan yang digunakan. Penelitian berikutnya disarankan untuk menggabungkan pendekatan yang digunakan yaitu pendekatan produksi (the production approach), pendekatan intermediasi (the intermediation approach), dan pendekatan asset (the asset approach).

\section{DAFTAR PUSTAKA}

Akhtar MH. 2010. E-Efficiency Analysis of Pakistani Commercial Banks. International Management Review 6(1):12-24.

Baltagi BH. 2005. Econometric Analysis of Panel Data. England: John Wiley \& Sons LTD.

Banerjee, Biswajit. 2012. Banking Sector Efficiency in New EU Member State: A Survey. Banka Slovenije. http://www.bsi.si/iskalniki/razisk ave.asp?MapaId=234. [10 Juli 2014].

Bank Indonesia. 2013. Statistik Perbankan Indonesia (SPI) bulan Januari 2013. http:// www. Bi.go.id. [6 Juni 2013].

Berger AN. et al. 1993. The Efficiency of Financial Institutions: A Review and Preview of Research Past, Present, and Future. Journal of Banking and Finance 17:221249.

Berger AN. Humprey DB. 1997. Efficiency of Financial Institution: International Survey and Direction for Future Research.

fic.wharton.upenn.edu/. Februari 2013].

Berger AN. Mester LJ. 1997. Inside the Black Box: What Explains 
Differences in The Efficiencies of Financial Institutions.

fic.wharton.upenn.edu/.

Februari 2013].

Gujarati, Damodar N. (2004). Basic econometrics, fourth edition. The Mcgraw-Hill Companies.

Hadad MD. et al. 2003. Pendekatan Parametrik untuk Efisiensi Perbankan Indonesia. http://www.bi.go.id. [5 Juli 2012].

Mohamad, Karnoto. 2012. Berburu 115 Juta Unbanked. Majalah Infobank No.398. Jakarta.

Repkova I. Miglietti CL. 2014. Cost and Profit Efficiency of The Slovak Banking Sector. http://icfb.rs.opf.slu.cz/. [10 Juli 2014].
Sealey, C. And Lindley, J. 1977. Inputs, Outputs, and a theory of production and cost at depository financial institutions. Journal of Finance 32:1251-1266.

Sekretariat Negara. 1998. UndangUndang Republik Indonesia No. 10 Tahun 1998 tentang Perubahan atas Undang-Undang No. 7 Tahun 1992 tentang Perbankan. Jakarta.

Sillah BMS. et al. 2014. The Performance of Saudi Banking Industry 2000 -2011: Have the Banks Distinguished Themselves from One Another? International Journal of Financial Research. www.sciedu.ca/ijfr. $\quad[10 \quad$ Juli 2014]. 